\title{
Reporting the Troubles: Journalists Tell Their Stories of the Northern Ireland Conflict, Deric Henderson, Ivan Little (eds.)
}

\section{Fabrice Mourlon}

\section{(2) OpenEdition}

Journals

Édition électronique

URL : https://journals.openedition.org/etudesirlandaises/8681

DOI : 10.4000/etudesirlandaises.8681

ISSN : 2259-8863

Éditeur

Presses universitaires de Caen

Édition imprimée

Date de publication : 31 décembre 2019

Pagination : 159-161

ISBN : 978-2-84133-964-8

ISSN : 0183-973X

Référence électronique

Fabrice Mourlon, « Reporting the Troubles: Journalists Tell Their Stories of the Northern Ireland Conflict, Deric Henderson, Ivan Little (eds.) », Études irlandaises [En ligne], 44-2 | 2019, mis en ligne le 06 mai 2020, consulté le 14 novembre 2022. URL : http://journals.openedition.org/etudesirlandaises/8681 DOI : https://doi.org/10.4000/etudesirlandaises.8681

Creative Commons - Attribution - Pas d'Utilisation Commerciale - Partage dans les Mêmes Conditions 4.0 International - CC BY-NC-SA 4.0

https://creativecommons.org/licenses/by-nc-sa/4.0/ 
l'histoire de l'Irish Cultural Revival. Le chapitre suivant se tourne vers la ville et le corps avec le théâtre de Beckett et propose une belle analyse, fortement appuyée sur les écrits critiques de Stacy Alaimo et son concept de trans-corporalité, du corps de Maddy Rooney, protagoniste de All That Fall, comme non seulement stérile mais aussi en plein échange de matière avec son environnement dans un processus de dissolution / liquéfaction. Lisa FitzGerald analyse les versions données par Pan Pan de plusieurs pièces de Beckett et la manière dont le son de ces pièces écrites pour la radio devient performance dans ces productions sur scène.

Après l'Ouest et Dublin, c'est vers l'espace contesté du Nord que Lisa FitzGerald tourne son attention à travers Field Day et deux pièces de Brian Friel, Translations et Making History. L'auteure s'appuie pour son analyse d'une production théâtrale non sur les productions originales mais sur la production in situ de Making History par Ourouboros qui a beaucoup tourné en Irlande avec l'aide de l'Office of Public Works mais a également été donnée au Centre culturel irlandais de Paris lors de la manifestation «Friel in Paris» en 2009. À l'évidence, jouer cette pièce dont le héros est Hugh O’Neill à Dungannon, dans le lieu où le dernier grand chef gaélique avait son château, permet, comme l'affirme Lisa FitzGerald, de confronter directement le spectateur à l'histoire dans la matérialité d'un lieu que le théâtre ranime.

Le dernier chapitre est certainement le plus original et ouvre des perspectives passionnantes autour de la question des archives numériques, de plus en plus nombreuses et variées, et de leur statut car ces objets à la matérialité ambivalente (réseau, espaces numériques) remettent en cause le caractère éphémère et non reproductible de l'acte théâtral; dans le cadre théorique matérialiste qui est le sien, l'auteure plaide pour une inclusion dans l'analyse de ce qui demeure après l'événement, de ce que la représentation laisse comme documentation d'elle-même et de sa conception.

L'immense mérite de ce travail est d'illustrer de manière concrète dans le domaine de la critique théâtrale ce qui se joue depuis de nombreuses années dans la pratique, avec le développement de formes théâtrales de plus en plus hybrides, sans oublier tout le mouvement in situ qui dans ses formes les plus abouties fait dialoguer espace et acteurs, humain et non-humain, objet culturel et environnement naturel. La réflexion proposée nous engage à re-placer ou rem-placer certains modes de lecture et d'analyse, à regarder différemment la relation nature / culture à la lumière de la crise environnementale qui interroge la place du vivant dans nos sociétés.

Martine Pelletier

\section{Reporting the Troubles: Journalists Tell Their Stories of the Northern Ireland Conflict, Deric Henderson, Ivan Little (eds.), Newtownards, Blackstaff Press, 2018, 238 p.}

Reporting the Troubles is the latest addition to a number of collections of testimonial narratives, both a genre and a practice that developed in the aftermath of the Good 
Friday Agreement of 1998 in Northern Ireland. These publications participate in the drawn-out process of dealing with the past in which acknowledging and remembering the human cost of a protracted conflict is central as well as the search for "truth and justice" in so-called cold cases.

The practice of gathering people's personal experience of the conflict started in the late 1990s with the aim of drawing lessons from the past by exposing the suffering and loss endured by the population, but also documenting events in the tradition of history from below. Considered as oral history by some or therapeutic accounts by others, these testimonies originally focused on victims and survivors or everyday people and later acknowledged members of institutions such as the police or the British Army in an attempt to include all parties of the conflict in the remembering process and give them equal space to tell their stories. Inclusivity being seen as paramount in a divided society where the definition of victimhood is contested.

This volume follows the path of these books and compiles seventy narratives by journalists who covered the conflict from 1968 to the early 2000s. They were asked to write about defining moments that marked their career and personal experience. The objectives of the project are clearly stated by Senator George J. Mitchell in his foreword and by local journalists Deric Henderson and Ivan Little in the introduction to the book: tribute should be paid to the journalists who have worked in harrowing conditions to report on the violence, despite intimidations from paramilitary organisations and government pressure; their recollection of events should be deeply personal with a focus on their emotions so as to leave an strong impression on the reader; finally the volume is meant to mark the $20^{\text {th }}$ anniversary of the signing of the Good Friday Agreement and the $50^{\text {th }}$ anniversary of the beginning of the Troubles. However, the on-going negotiations about how the United Kingdom will leave the European Union have heightened tensions about the constitutional future of Northern Ireland and marred the prospect of restoring the local government and institutions. This volatile situation makes the publication of Reporting the Troubles all the more necessary as it attempts to thwart the possible return to violence. Indeed the book covers the major events of the conflict and insists on its impact on the population.

The focus on emotions and traumatic events however can be overwhelming for the reader especially as the texts themselves are very short, and leave an impression of incremented pain. The vicarious trauma felt by the journalist is passed on to the reader. One may wonder whether emotions alone can have a transformative effect on the reader. Other narratives tell the story of meetings and relationships between the journalists and prominent political figures such as Ian Paisley, Martin McGuinness, Margaret Thatcher, or John Hume. This adds a more political dimension to the collection of texts. However the contents of those testimonies do not provide more information than other research has already produced.

This book remains an invaluable and timely contribution to initiatives that have pushed for the creation of mechanisms and space to deal with the past in Northern Ireland, when the latest consultation on the issue was not able to build a consensus on the form it should take, and when the population, especially the young generation born after the conflict, will need to make sense of its troubled past. 
This compilation of testimonies by journalists can be considered as a memorial in itself and will be added to the archives of other testimonies that have been gathered over the last twenty years to be studied by future historians.

Fabrice MOURLON

\section{Eoin Swithin Walsh, Kilkenny: In Times of Revolution, 1900-1923, Newbridge, Merrion Press, 2018, 350 p.}

The recent death of Professor David Fitzpatrick has deprived modern Irish history of one of its most important scholars. A remarkable researcher and an incisive writer, Fitzpatrick helped pioneer Irish Diaspora and First World studies, mentoring a talented generation of historians in the process. Perhaps Fitzpatrick's greatest contribution was his work on Revolutionary Ireland, most notably his groundbreaking study of County Clare, Politics and Irish Life, 1913-1921: Provincial Experience of War and Revolution (Dublin, Gill \& Macmillan, 1977). His novel approach inspired important local studies by historians like Peter Hart, Joost Augusteijn, Marie Coleman, Michael Farry, and Padraig Yates, to just name a few. Still following Fitzpatrick's model three decades later, Four Courts Press's "The Irish Revolution, 1912-1923” series (edited by Mary Ann Lyons and Daithí Ó Corráin) has expanded our understanding of the revolutionary experience by producing local studies (nine and counting) of less-obvious counties like Louth, Monaghan, and Waterford. The Four Courts series reuses the same rough template in terms of periodisation (19131923) and focus (social/ economic as well as political/military), which allows for easy comparisons between the counties. While the field becomes more crowded, space remains for different approaches to the county study. One such example is Eoin Swithin Walsh's new book, Kilkenny: In Times of Revolution, 1900-1923.

In terms of revolutionary intensity, County Kilkenny has been relegated to the second division by historians, who have generally accepted Ernie O'Malley's description of the Kilkenny IRA "slack" during the War of Independence. Eoin Swithin Walsh does not fundamentally revise that interpretation, but he adds considerable nuance to it. The work can be characterised primarily as a military history, mostly relating to the 1919 to 1923 period, despite the title. The methodology is somewhat conventional and narrow, though it does produce some gems. Of note is an examination of republican governance during the War of Independence, primarily via local bodies and the Dáil Éireann underground administration. The author incorporates Cumann na mBan into his main narrative, as a featured participant rather than in a passing cameo. Gender-based violence also receives notice, including hair-shorning, a topic Linda Connolly has recently drawn attention to. The author should be especially praised for identifying every violent death in County Kilkenny during the War of Independence and Civil War. This kind of pain-staking research is a service to both scholars and the interested public. Frequently the narrative is enlivened by entertaining portraits of 